\title{
Species assemblages of leptocephali in the southwestern Sargasso Sea
}

\author{
Michael J. Miller ${ }^{1, *}$, James D. McCleave ${ }^{2}$ \\ ${ }^{1}$ Ocean Research Institute, University of Tokyo, Minamidai, Nakano, Tokyo 164-8639, Japan \\ ${ }^{2}$ School of Marine Sciences, University of Maine, Orono, Maine 04469, USA
}

\begin{abstract}
Catches of leptocephali of shelf and slope marine eels of the Chlopsidae, Congridae, Moringuidae, Muraenidae, and Ophichthidae collected during a survey in the southwestern Sargasso Sea in late September and early October 1984 were analyzed to learn about their reproductive ecology and larval transport. Sampling along a transect from the Florida Current (FC) out across the southwestern Sargasso Sea and in the Northwest Providence Channel (NWPC) of the Northern Bahamas enabled the evaluation of the larval distributions, abundances and size ranges, regional assemblage structure, and the apparent spawning areas of these marine eels. Distinctly different assemblages observed in the FC and NWPC included the congrid genera Heteroconger, Paraconger, Uroconger, and many ophichthid species, which were rare or absent offshore. Other taxa of congrids, chlopsids, muraenids and moringuids were present in all areas, but the smallest specimens of most taxa were only caught at the NWPC or FC stations. Multivariate analyses reflected higher richness and abundance in the FC and NWPC and also similar species compositions in offshore areas. The patterns of distribution of these leptocephali differed from those of anguillid, nettastomatid, and mesopelagic eel leptocephali collected in the same survey. These findings support the hypothesis that most taxa of marine eels spawn close to their adult habitats, and indicate that despite high biodiversity of marine eels in the Northern Bahamas, only some species of leptocephali appear to get transported far offshore by ocean currents.
\end{abstract}

KEY WORDS: Leptocephali · Larval distribution · Marine eels · Spawning area · Sargasso Sea · Northern Bahamas · Florida Current

- Resale or republication not permitted without written consent of the publisher

\section{INTRODUCTION}

The southwestern Sargasso Sea of the western North Atlantic Ocean (WNA) is unique because of its shallow continental shelf areas or banks and the presence of the Florida Current (FC) and Gulf Stream along its margins. A remarkable feature of the region is the large shallow banks of the northern Bahama Islands at the southwestern edge of the Sargasso Sea (see Fig. 1), which are surrounded by water 600 to $4500 \mathrm{~m}$ deep. The strong flow of the FC passes northward just west of the northernmost Bahama Banks and flows along the east coast of Florida and the South Atlantic Bight (SAB) before turning to the east off Cape Hatteras and becoming the Gulf Stream along the northern margin of the Sargasso Sea (Schott et al. 1988). The central
Sargasso Sea is the location of the Subtropical Convergence Zone (STCZ), where distinct bands of temperature fronts form in the fall and winter (Halliwell et al. 1991), and likely dissipate during the summer months.

During late winter and spring, the region of the Sargasso Sea to the south of these fronts is renowned as the spawning area of the 2 species of Atlantic anguillid eels, the American eel Anguilla rostrata, and the European eel A. anguilla. The larvae (called leptocephali) of these 2 species then become widely distributed in the Sargasso Sea (Schoth \& Tesch 1982, McCleave \& Kleckner 1987, Kleckner \& McCleave 1988, McCleave 1993) before many move westward into the FC and are transported to the north (Kleckner \& McCleave 1982). Those of A. rostrata must then detrain from the current to recruit to North America, 
and those of A. anguilla continue moving to the northeast towards Europe in the Gulf Stream and then the North Atlantic Drift (McCleave 1993).

Surveys for anguillid leptocephali also have found that the mesopelagic eels and gulpers of the families Derichthyidae, Cyematidae, Eurypharyngidae, Nemichthyidae, and Serrivomeridae spawn in the open ocean of the Sargasso Sea (Castonguay \& McCleave 1987a, Miller \& McCleave 1994, Smith \& Miller 1996, Wippelhauser et al. 1996). In addition, the marine eel Conger oceanicus, which lives along the US East Coast, also migrates to spawn in the southern Sargasso Sea (McCleave \& Miller 1994), as the congrid eel Ariosoma balearicum from the SAB seems to do also (Miller 2002a). However, extensive surveys for anguillid leptocephali in the Sargasso Sea provided no evidence that other marine eels from shallow shelf or continental slope areas spawn offshore in the region (Castle 1979, Miller \& McCleave 1994, Miller 1995).

Evidence of where most eels spawn has only been obtained from studies on the distribution and size ranges of their leptocephali, because eels are especially difficult to study due to their nocturnal and often fossorial behavior that makes them hard to collect or observe. Therefore, collections of their leptocephali probably represent the most practical method with which to learn about their biodiversity and life histories in various regions where the adult fauna is poorly known (Blache 1977, Miller et al. 2002, 2006, Minagawa et al. 2004, Richardson \& Cowen 2004, Wouthuyzen et al. 2005). These larvae are long lived and can drift far from their birthplace compared with many other fish larvae, so analyses of their distributions can also be used to assess patterns of ocean circulation if the spawning area of a particular species is known.

Studies on leptocephali have been useful for learning about the life history of individual species or taxa in various regions (e.g. Castle 1979, Castonguay \& McCleave 1987a, McCleave \& Miller 1994, Wippelhauser et al. 1996, Miller 2002a, Miller et al. 2006) because the leptocephali of all different types of eels and their relatives can be collected together in the upper few hundred meters of the ocean (Castonguay \& McCleave 1987b). Some adult eels live in the mesopelagic zone or in deep benthic habitats, but the majority of species live on the continental shelf or slope or around islands. The Bahama Islands and their surrounding banks provide habitats for a wide variety of marine eels (Böhlke 1989a), and various species must also live in the Florida Keys, the SAB, and Bermuda. Most shallow water and continental slope eel species appear to spawn close to their juvenile and adult habitats (Miller 2002b), but some leptocephali get transported offshore to areas such as the Sargasso Sea where they have been consistently collected (Castle 1979, Keller 1976, Miller \& McCleave 1994, Miller 1995). The Sargasso Sea is a good place to study life histories of the eel fauna because it is one of the few regions of the world where most types of leptocephali have been matched to adult species (Böhlke 1989b). This enabled the analysis of the species assemblages of leptocephali collected during sampling surveys targeting anguillid leptocephali in the Sargasso Sea during the February to April season (Miller \& McCleave 1994, Miller 1995), but studies on the assemblages of leptocephali in other seasons have not been published.

In this study, the species composition, distribution, size ranges, relative abundance, and assemblages of leptocephali of 5 families of shelf and slope eels (Chlopsidae, Congridae, Moringuidae, Muraenidae, and Ophichthidae) were analyzed from collections made during a research cruise in the fall season in 1984 that targeted leptocephali at stations from the FC across the southwestern Sargasso Sea and in the Northwest Providence Channel (NWPC). These families include many species that live in association with coral reefs and seagrass beds, and in sand or mud substrates in shallow areas and on the upper continental slope down to about $1000 \mathrm{~m}$ or deeper (Böhlke 1989a). The leptocephali of anguillid and mesopelagic eels were studied in relation to the oceanographic conditions during this survey (Castonguay \& McCleave 1987a, McCleave \& Kleckner 1987, Wippelhauser et al. 1996). The published and unpublished data on the distribution and abundance of anguillid, mesopelagic and nettastomatid eel leptocephali that were collected are also presented here and used in an overall analysis of the assemblage structure of leptocephali in order to gain a broad perspective of the reproductive ecology and larval distributions of anguilliform eels in relation to the geography and current patterns in the region.

\section{MATERIALS AND METHODS}

Study area. The Sargasso Sea is part of the western half of a large anticyclonic gyre that includes the western boundary current, referred to as the FC and the Gulf Stream, which flows to the north and northeast along the Atlantic coast of North America (Schmitz \& McCartney 1993). The southern half of this flow, from the Straits of Florida to Cape Hatteras, is narrow with minor meanders and is called the FC (Schott et al. 1988). It transports water from the Caribbean, Gulf of Mexico and more distant regions through the Straits of Florida, combines with Gulf Stream recirculation water from the Sargasso Sea as it flows north of the Bahamas (Marchese 1999), and forms the Gulf Stream off Cape Hatteras. Past Cape 
Hatteras, the Gulf Stream usually has pronounced meanders, which sometimes become separated and cast off to the north as warm-core rings or to the south as cold-core rings (Richardson 1983). The FC and Gulf Stream form the western and northern boundary of the Sargasso Sea, but the southernmost part of the FC is separated from the southwest Sargasso Sea by the shallow banks of the Northern Bahamas (see Fig. 1). The 2 largest banks of the Bahamas are separated by the Providence Channel, which connects the Sargasso Sea and FC.

The central part of the Sargasso Sea, between 22 and $32^{\circ} \mathrm{N}$, is the location of the STCZ, which has a dynamic pattern of fronts during winter and spring. These fronts form in the upper $200 \mathrm{~m}$, where colder water in the north meets the warmer mixed layer of lower density water in the upper $100 \mathrm{~m}$ in the south (Kleckner \& McCleave 1988, Eriksen et al. 1991, Halliwell et al. 1991). In the STCZ, 2 or 3 latitudinal bands of fronts are evident in satellite imagery of sea surface temperature (Halliwell et al. 1991), but their locations and movements vary. Surface water converges toward the fronts where strong frontal jets occur (Eriksen et al. 1991). During summer, these fronts dissipate as the surface layer warms, and a general westward flow is thought to occur in the southern Sargasso Sea, as has been seen in some drifter tracks (Reverdin et al. 2003).

Various current patterns have been seen off Abaco Island on the northeast side of the Northern Bahamas during different months (Hacker et al. 1996), suggesting that a complex pattern of circulation is often present in the region. The northwestward flow just off Abaco Island is referred to as the Antilles Current, and it appears to be present throughout most of the year (Meinen et al. 2004). Some of the water from the southern Sargasso Sea also flows southward through the passages of the Greater Antilles into the Caribbean Sea, and some passes through the NWPC and into the FC (Johns et al. 1999). During the cruise described in the present study in late September and early October of 1984, conductivity, temperature, depth (CTD; 0 to $500 \mathrm{~m}$ ) and expendable bathythermograph (XBT) profiles were made at each station, which showed that there was a mixed layer of warm water in the upper 50 to $100 \mathrm{~m}$ throughout the study area (see McCleave \& Kleckner 1987).
Sampling methodology. The cruise (RV 'Columbus Iselin CI8410') was conducted from 29 September to 19 October 1984 by the University of Maine to study Anguilla spp. leptocephali (McCleave \& Kleckner 1987). Sampling consisted of a transect of 9 stations extending from the FC southeast into the Sargasso Sea from $31^{\circ} 50^{\prime} \mathrm{N}, 78^{\circ} 44^{\prime} \mathrm{W}$ to $24^{\circ} 50^{\prime} \mathrm{N}, 69^{\circ} 45^{\prime} \mathrm{W}$ (Fig. 1). There was also a southwest transect of 3 stations from approximately the middle of the main transect into the NWPC of the Northern Bahamas: $27^{\circ} 52^{\prime} \mathrm{N}, 73^{\circ} 36^{\prime} \mathrm{W}$ to $26^{\circ} 14^{\prime} \mathrm{N}, 78^{\circ} 39^{\prime} \mathrm{W}$.

Leptocephali were collected at night with a $3 \mathrm{~m}$ Isaacs Kidd Midwater Trawl (IKMT) with a mouth area of $8.7 \mathrm{~m}^{2}$ and $1.8 \mathrm{~mm}$ NITEX netting. Two replicate tows were made at all stations with the IKMT being deployed in triple oblique tows designed to sample all strata evenly to a depth of about $100 \mathrm{~m}$. Fishing depth of the trawl was assessed with a pressure-sensitive ultrasonic transmitter and receiver system and a timedepth recorder, and the amount of water filtered was estimated using a flowmeter in the mouth of trawl. Tows averaged $169 \pm 27 \mathrm{~min}(\operatorname{mean} \pm \mathrm{SD})$ at $101 \pm 2 \mathrm{~m}$ maximum depth, with $8.0 \pm 1.6 \times 10^{4} \mathrm{~m}^{3}$ of water filtered (McCleave \& Kleckner 1987). Plankton samples were immediately preserved in $7.5 \%$ seawater-

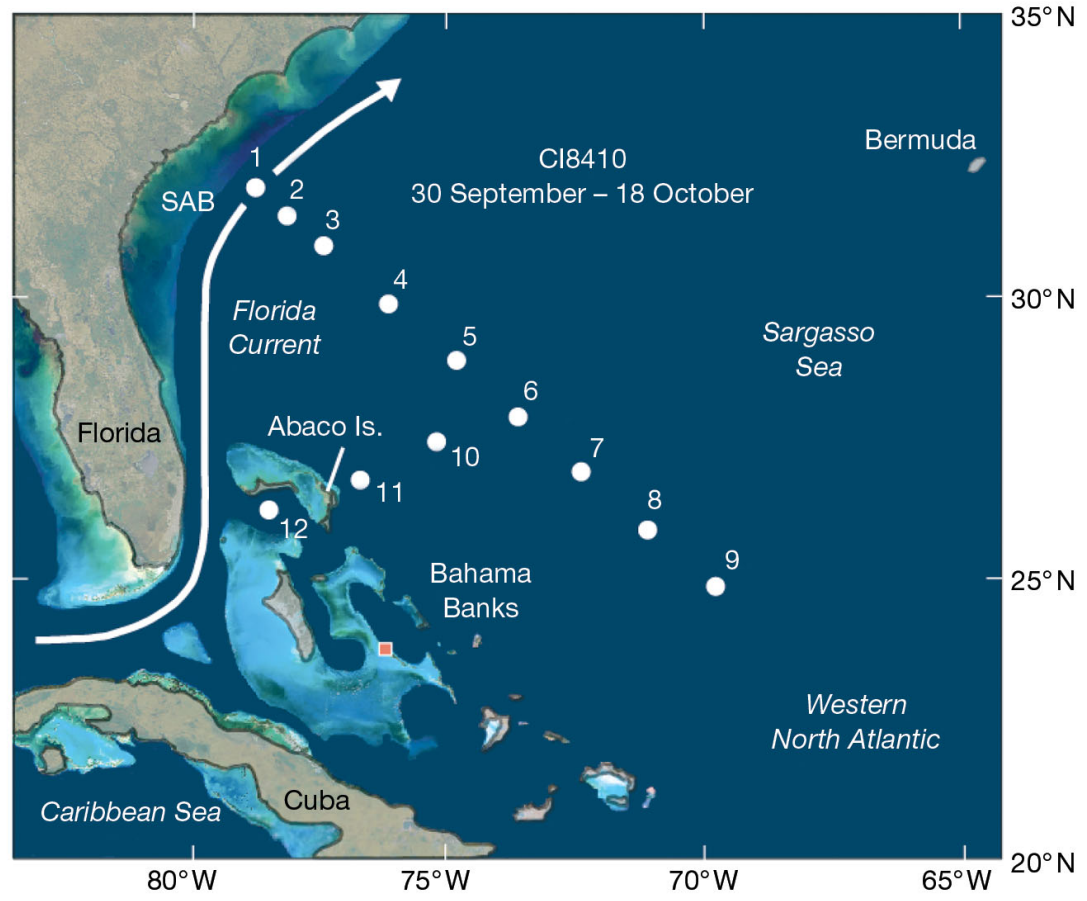

Fig. 1. Location of stations (Stns 1-12) during the CI8410 sampling survey from 30 September to 18 October 1984, plotted along with modified SeaWiFS satellite imagery, which shows shallow areas of the South Atlantic Bight (SAB), Northern Bahamas, etc. that have bottom depths of $<200 \mathrm{~m}$ in light blue or green. The red square shows where leptocephali were collected as they recruited to the Grand Bahama Bank during a previous study (Shenker et al. 1993) 
formalin buffered with $\mathrm{CaCO}_{3}$, and the leptocephali were identified later in the laboratory following Böhlke (1989b).

Data analysis. The assemblages of leptocephali of 26 species or taxa of the 5 families that were the focus of this study were compared using agglomerative, hierarchical cluster analysis and non-metric multidimensional scaling (MDS) (Field et al. 1982). These taxa corresponded to those shown in Table 1, except that species for which only 4 or fewer specimens were collected (28 species), or those that could not be adequately identified (Congrinae spp., Muraenidae spp.), were excluded from the analysis. For comparison, the assemblages of 7 species of catadromous (Anguilla anguilla and $A$. rostrata) and mesopelagic (oceanic) species (Derichthys serpentinus, Nessorhamphus ingolfianus, Labichthys carinatus, Nemichthys scolopaceus, and Serrivomer brevidentatus), which spawn offshore in the Sargasso Sea, were also analyzed using the same techniques. With the exception of $S$. brevidentatus, the data for these species were from previously published reports (Castonguay \& McCleave 1987a, McCleave \& Kleckner 1987, Wipplehauser et al. 1996). The third analysis combined the first and second groups of species as well as 2 nettastomatid species (Nettenchelys pygmaea and Nettastoma sp.), whose juveniles and adults live on the outer shelf and slope but probably do not migrate into the open ocean to spawn. The catch rates of each taxon at each station were calculated using the volume of water filtered and were represented as the number of individuals per $10^{5} \mathrm{~m}^{3}$ of water filtered (ind. $/ 10^{5} \mathrm{~m}^{3}$ ) as in previous assemblage studies of leptocephali (Miller \& McCleave 1994, Minagawa et al. 2004, Miller et al. 2006).

Cluster analysis of catch rates used the Bray-Curtis measure with the unweighted pair-group method (UPGMA) after the values were root-root transformed to scale the values so that the dominant taxa would not be overemphasized (Field et al. 1982). The MDS was performed using the same dissimilarity matrix as in the cluster analysis. MDS finds the best overall fit of the points (station assemblages) in 2- or 3-dimensional space based on the individual dissimilarities between all the pairs of points, and provides a way to visualize the relationships among all the assemblages and to evaluate the results of the cluster analysis. To investigate the underlying reasons for the grouping patterns generated by cluster analysis of the 26 taxa, SIMPER analysis (Clarke \& Warwick 1994) was applied to the dissimilarity matrix to determine which taxa most typified the groups identified from the results of the cluster analysis and ordination.

Species richness values were based on the minimum number of species at each station, without distinguishing taxa that are hard to consistently separate morpho- logically, and the same level of separation was used in the species diversity and evenness calculations. The individual species of the genera Gnathophis, Paraconger, Heteroconger and the muraenid leptocephali not conforming to the species of Smith (1989a) were not distinguished. Species diversity was calculated using catch rates to compensate for different sampling effort by both Shannon-Wiener's evenness index $\left(H^{\prime}\right)$ and Hill's N1 (Exp $\left.H^{\prime}\right)$ for ease of comparison with other recent studies on leptocephali (Minagawa et al. 2004, Wouthyuzen et al. 2005). Hill's N2 (1/D: reciprocal of Simpson's index $D$ ) was used as a measure of the evenness of a sample.

Statistical comparisons of the lengths of abundant taxa in different areas were made using either parametric ( $t$-tests or ANOVA) or non-parametric ( $U$-tests or Kruskal-Wallis) tests, depending on whether the data were normally distributed with equal variances or not, and were followed by pair-wise tests (Tukey and Dunn's tests, respectively) with a criterion for significance of $p<0.05$. Comparisons were made among 2 to 4 different areas: the FC (Stns 1, 2), the offshore Sargasso Sea (Stns 3 to 9), the region northeast of Abaco Island (Stns 10, 11), and the NWPC (Stn 12).

\section{RESULTS}

\section{Taxonomic composition}

There were 2904 leptocephali from at least 62 species of the 5 families of marine eels included in this study. Leptocephali of the Congridae were most abundant, with 22 species collected $(\mathrm{N}=1460)$, compared with the less abundant Chlopsidae ( 6 species, $N=575$ ), Muraenidae ( $\geq 10$ species, $N=298)$, Ophichthidae (22 species, $N=270$ ), and Moringuidae (2 species, $N=194$ ) (Table 1). The greater abundance of congrids was due primarily to large numbers of Ariosoma balearicum collected throughout the study area, which comprised $41 \%$ of the total catch. The other widespread and abundant species were the chlopsids Chilorhinus suensonii and Kaupichthys hyoproroides, the morniguid Moringua edwardsi, and the muraenid Gymnothorax moringa, which collectively comprised $50 \%$ of leptocephali other than A. balearicum.

Several genera of congrids are difficult to identify to species due to similar or overlapping ranges of myomere counts (Smith 1989b), so not all the different species were listed in Table 1. For example, Gnathophis bathytopos, G. bracheatopos, and G. tritos could not always be distinguished because the vertebral ranges of their adults overlap too much. Similarly, there were 26 Bathycongrus spp. (formerly genus Rhechias) collected, which included $B$. thysanochila $(\mathrm{N}=9)$ as the 
Table 1. Number of leptocephali of 5 families of marine eels collected in the Florida Current (FC; Stns 1, 2), southwestern Sargasso Sea (Stns 3 to 11), and the Northwest Providence Channel of the Northern Bahamas (NWPC; Stn 12), with the minimum number of species of each taxa in parentheses. Shannon-Wiener $\left(H^{\prime}\right)$ and Hill's N1 (Exp $\left.H^{\prime}\right)$ diversity indices and Hill's N2 measure of evenness for each station are also shown

\begin{tabular}{|c|c|c|c|c|c|c|c|c|c|c|c|c|c|}
\hline & & & & & & & Stn & & & & & & Total \\
\hline & 1 & 2 & 3 & 4 & 5 & 6 & 7 & 8 & 9 & 10 & 11 & 12 & \\
\hline Congridae (21) & & & & & & & & & & & & & \\
\hline Ariosoma balearicum & 7 & 16 & 18 & 114 & 54 & 73 & 39 & 10 & 36 & 45 & 38 & 729 & 1170 \\
\hline Ariosoma anale & & & 1 & & & & & & & & & & 1 \\
\hline Ariosoma selenops & 1 & & & 1 & & & & & 2 & & & & 4 \\
\hline Parabathymyrus oregoni & & & & & & 1 & & & & & & 1 & 2 \\
\hline Paraconger spp. (2) & 33 & 21 & & & & & & & & & 1 & 27 & 82 \\
\hline Conger oceanicus & 3 & 1 & & & & 3 & 1 & 1 & 4 & & 10 & 6 & 29 \\
\hline Conger triporiceps & & & & & & 4 & 2 & & 1 & & 1 & 24 & 32 \\
\hline Conger esculentus & & 1 & & & & & & & & & & 1 & 2 \\
\hline Gnathophis spp. (3) & & 4 & 4 & 7 & 3 & 12 & 4 & 2 & 6 & & 5 & 4 & 51 \\
\hline Bathycongrus spp. (4) & & 6 & 3 & 1 & & 2 & 3 & 1 & 3 & 1 & & 6 & 26 \\
\hline Rhynchoconger flavus & & 2 & & & & & & & & & & & 2 \\
\hline Uroconger syringinus & & 6 & & & & & & & & & 1 & 4 & 11 \\
\hline Xenomystax congroides & & & & 6 & 5 & 1 & 1 & 1 & 3 & 2 & & & 19 \\
\hline Heteroconger (2) & 8 & 8 & & & & & & & & 1 & & 41 & 58 \\
\hline Congrinae spp. & & 4 & & & & 2 & & 2 & & & 5 & & 13 \\
\hline Chlopsidae (6) & & & & & & & & & & & & & \\
\hline Chilorhinus suensonii & 6 & 16 & 3 & 5 & 1 & 8 & 7 & 6 & 10 & 12 & 2 & 231 & 307 \\
\hline Kaupichthys hyoproroides & 4 & 10 & 14 & 3 & 5 & 45 & 14 & 3 & 23 & 25 & 7 & 74 & 227 \\
\hline Kaupichthys nuchalis & 8 & 2 & 1 & & & 2 & 2 & & 3 & 1 & & 6 & 25 \\
\hline Chlopsis bicolor & & 1 & & & & 1 & 1 & & & & & 1 & 4 \\
\hline Chlopsis dentatus & & & & & 1 & & 1 & & & & & & 2 \\
\hline Robinsia catherinae & & & & 3 & & 1 & & & & & 1 & 8 & 13 \\
\hline Moringuidae (2) & & & & & & & & & & & & & \\
\hline Moringua edwardsi & 20 & 30 & 4 & 3 & 4 & 13 & 4 & 6 & 5 & 12 & 7 & 82 & 190 \\
\hline Neoconger mucronatus & & 3 & & & & & & & & & & 1 & 4 \\
\hline Muraenidae (>10) & & & & & & & & & & & & & \\
\hline Gymnothorax moringa & 38 & 31 & 12 & 2 & 2 & 11 & 3 & & 3 & 3 & 3 & 38 & 146 \\
\hline Gymnothorax ocellatus & & & & & 1 & & & & & & & 1 & 2 \\
\hline Gymnothorax vicinus & 5 & 3 & 4 & & 1 & 1 & 3 & & & 1 & 1 & 39 & 58 \\
\hline Anarchias similis & 5 & 1 & & 5 & 5 & 4 & 16 & & 6 & 2 & 1 & 7 & 52 \\
\hline Monopenchelys acuta & 2 & & & & & & 3 & & & & 1 & 1 & 7 \\
\hline Gymnothorax miliaris & & 5 & & & & 1 & 1 & 1 & 2 & & & 4 & 14 \\
\hline Uropterygius macularius & 9 & 5 & 1 & & 1 & 3 & 1 & & & & 2 & 6 & 28 \\
\hline Muraenidae sp. (>4 spp.) & 11 & 6 & 1 & 2 & & & 5 & 1 & & 1 & 1 & 25 & 53 \\
\hline Ophichthidae (22) & & & & & & & & & & & & & \\
\hline Ahlia egmontis & 12 & & 2 & & 1 & 1 & 4 & 1 & 4 & & 2 & 11 & 38 \\
\hline Myrophis platyrhynchus & 12 & 6 & & & & & & & & & & 29 & 47 \\
\hline Myrophis punctatus & 5 & 3 & 1 & & & & & & & 1 & 1 & 45 & 56 \\
\hline Mixomyrophis pusillipinna & & & & & & & & & & & & 3 & 3 \\
\hline Ichthyapus ophioneus & & & 1 & & & 1 & & & & & 1 & 54 & 57 \\
\hline Aprognathodon platyventris & 2 & & & & & & & & & & & 12 & 14 \\
\hline Quassiremus ascensionis & & & & & & & & & & & & 9 & g \\
\hline Myrichthys ocellatus & & & & & & & & & & & & 4 & 4 \\
\hline Callechelys muraena & & & & & & & & & & & & 3 & 3 \\
\hline Letharchus velifer & & & & & & & & & & & & 3 & 3 \\
\hline Myrichthys breviceps & 2 & & & & & & & & & & & 1 & 3 \\
\hline Ophichthus gomesii & & 1 & & & & & & & & & & 2 & 3 \\
\hline Ophichthidae sp. (10 spp.) & & & 2 & & & 1 & 1 & & & & & 17 & 21 \\
\hline Total leptocephali & 193 & 192 & 72 & 152 & 84 & 191 & 116 & 35 & 111 & 107 & 91 & 1560 & 2904 \\
\hline Number of species & 21 & 24 & 16 & 11 & 13 & 20 & 19 & 10 & 15 & 12 & 18 & 46 & $>62$ \\
\hline$H^{\prime}$ & 2.6 & 2.7 & 2.2 & 1.1 & 1.5 & 2.0 & 2.2 & 1.9 & 2.2 & 1.7 & 2.0 & 2.1 & \\
\hline Hill's N1 (Exp $\left.H^{\prime}\right)$ & 13.2 & 14.2 & 9.4 & 2.9 & 4.3 & 7.3 & 9.4 & 6.9 & 8.8 & 5.3 & 7.7 & 8.2 & \\
\hline Hill's N2 & 9.4 & 10.5 & 6.8 & 1.7 & 2.3 & 4.5 & 5.7 & 5.4 & 5.9 & 3.8 & 4.3 & 3.9 & \\
\hline
\end{tabular}


most abundant species, and others that were distinguished as B. vicinus, Bathycongrus sp. A, Bathycongrus sp. C, or Bathycongrus sp. The Paraconger spp. leptocephali may have been mostly P. caudilimbatus, but 2 specimens appeared to be $P$. guianensis, and 20 had myomere counts in the range of overlap between the 2 species. Most of the garden eel leptocephali were Heteroconger halis, but there were $3 \mathrm{H}$. luteolus collected at Stn 12.

The family Ophichthidae was represented by many species of leptocephali due to the collection of at least 20 species at Stn 12 in the NWPC, which were identified to species level according to Leiby (1989). There were 4 species of the subfamily Myrophinae and 18 of the Ophichthinae collected during the study, and 12 of the most abundant species were listed in Table 1. Other ophichthids included 1 to 3 specimens each of 8 species collected only in the NWPC (Apterichtus kendalli, Callechelys guineensis, Caralophia loxochila, Gordiichthys irretitus, Ophichthus ophis, Stictorhinus potamius, Ophichthini sp. 3 and sp. 4), and single specimens of Callechelys bilinearis and Echiophis punctifer collected at Stn 3 . All but 2 of the 22 ophichthid species were collected in the NWPC, and 13 of those were only collected there.

There were 10 species of leptocephali of the family Muraenidae that were identified, but far fewer types of
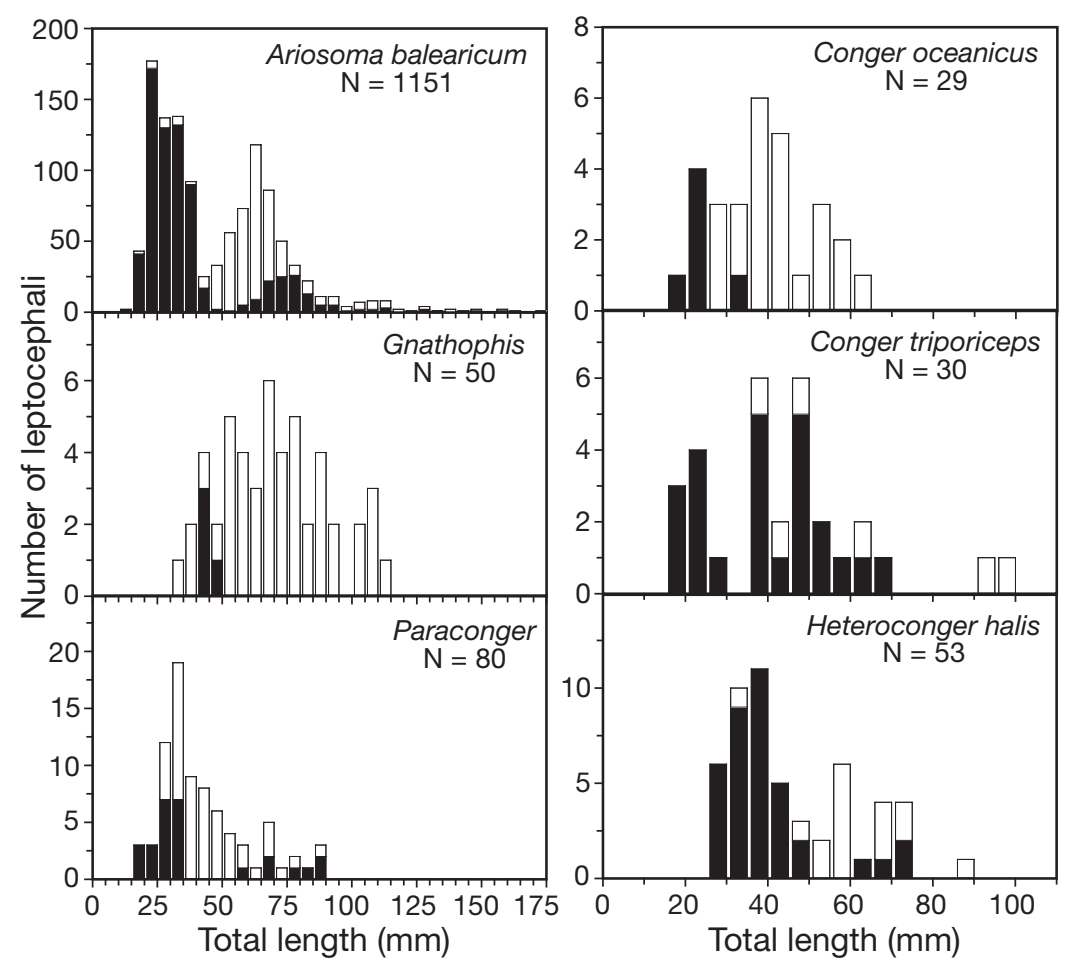

Fig. 2. Congridae. Length frequency distributions of leptocephali collected at Stn 12 in the Northwest Providence Channel (NWPC) shown with black bars; those collected at all other stations shown with white bars muraenid leptocephali have been distinguished in the WNA than the number of adult species (Böhlke 1989a, Smith 1989a). Smith (1989a) suggested that some of the types of leptocephali that could be distinguished, such as Gymnothorax moringa, G. vicinus, and G. ocellatus, were likely a complex of species whose adults have a similar range of vertebrae, and therefore that their leptocephali may be indistinguishable morphologically. Seven specimens of Gymnothorax sp. A, B, and C of Smith (1989a) were identified, and it is likely that there were additional muraenid species among the 213 Gymnothorax spp. and the 46 unidentifiable muraenids collected.

\section{Distribution and size of leptocephali}

The 4 most abundant species, Ariosoma balearicum (Figs. 2 \& 3), Chilorhinus suensonii, Kaupichthys hyoproroides, and Moringua edwardsi (Figs. 4 \& 5) varied widely in size and were collected at every station, but all other species showed various patterns of distribution in the study area. A. balearicum was collected at a variety of size ranges from the FC and across the Sargasso Sea, but at Stn 12 in the NWPC there was a distinct bimodal size range (Fig. 2). Large numbers of 15 to $40 \mathrm{~mm}$ leptocephali were collected in the NWPC, but the 40 to $75 \mathrm{~mm}$ size range was the most abundant offshore. The details of the distribution and size ranges of $A$. balearicum during this survey will be described elsewhere. Paraconger and Heteroconger also had 2 different size classes at Stn 12, but their leptocephali were almost exclusively collected there and at Stns 1 and 2 in the FC (Fig. 3). Like several other congrid species, their smallest leptocephali were collected in the NWPC. Conger triporiceps was also more abundant along with smaller sizes in the NWPC, but Conger oceanicus and Gnathophis leptocephali were more abundant offshore at a range of sizes of $>25 \mathrm{~mm}$ (Fig. 3). Xenomystax congroides was the only congrid species to be collected exclusively in the Sargasso Sea, but no specimens of $<50 \mathrm{~mm}$ were collected (Fig. 3).

Moringuids, muraenids and chlopsids typically reach a smaller maximum size than do congrids, and a wide size range was collected of most taxa (Fig. 4). The smallest sizes of most species were caught in the NWPC or FC (Fig. 5). Chilorhinus suensonii leptocephali as small as $8 \mathrm{~mm}$ 

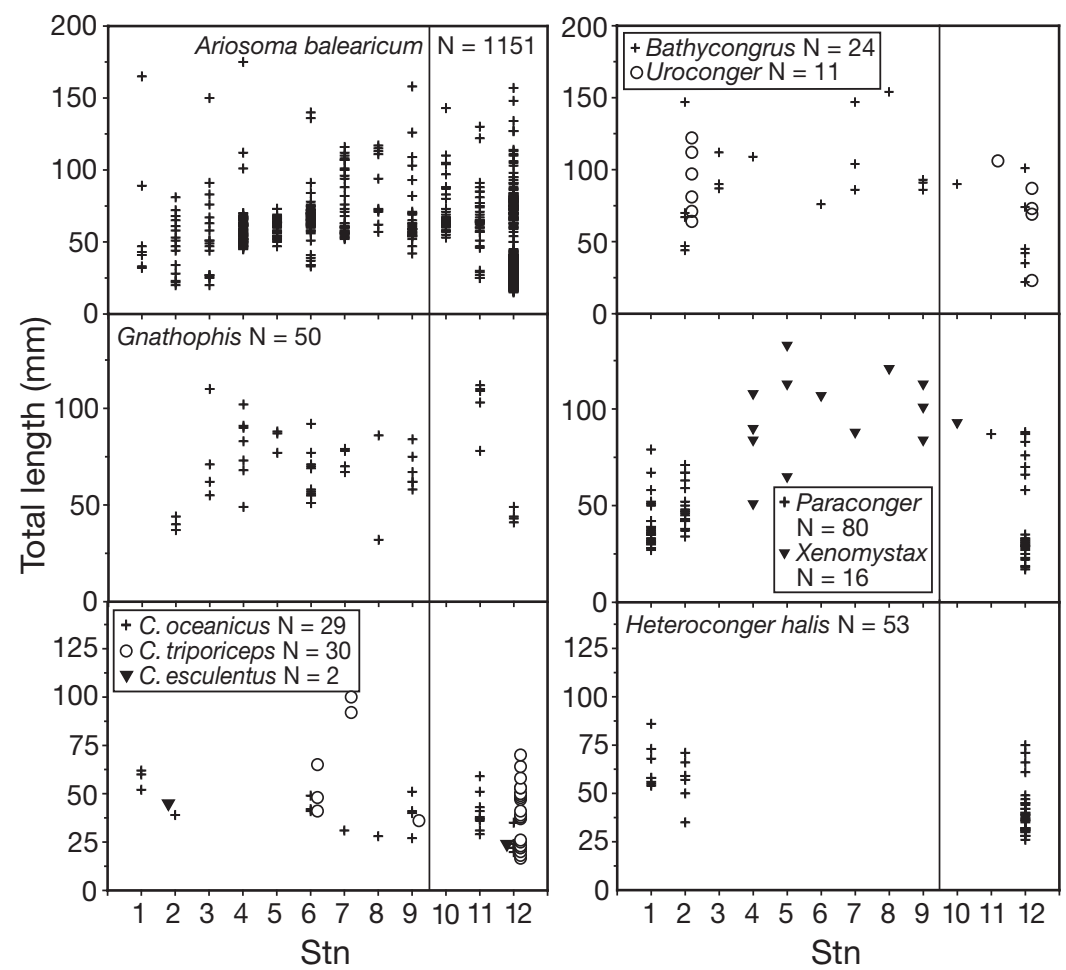

Fig. 3. Congridae. Lengths of individual leptocephali of 10 taxa collected at each station in the Sargasso Sea region
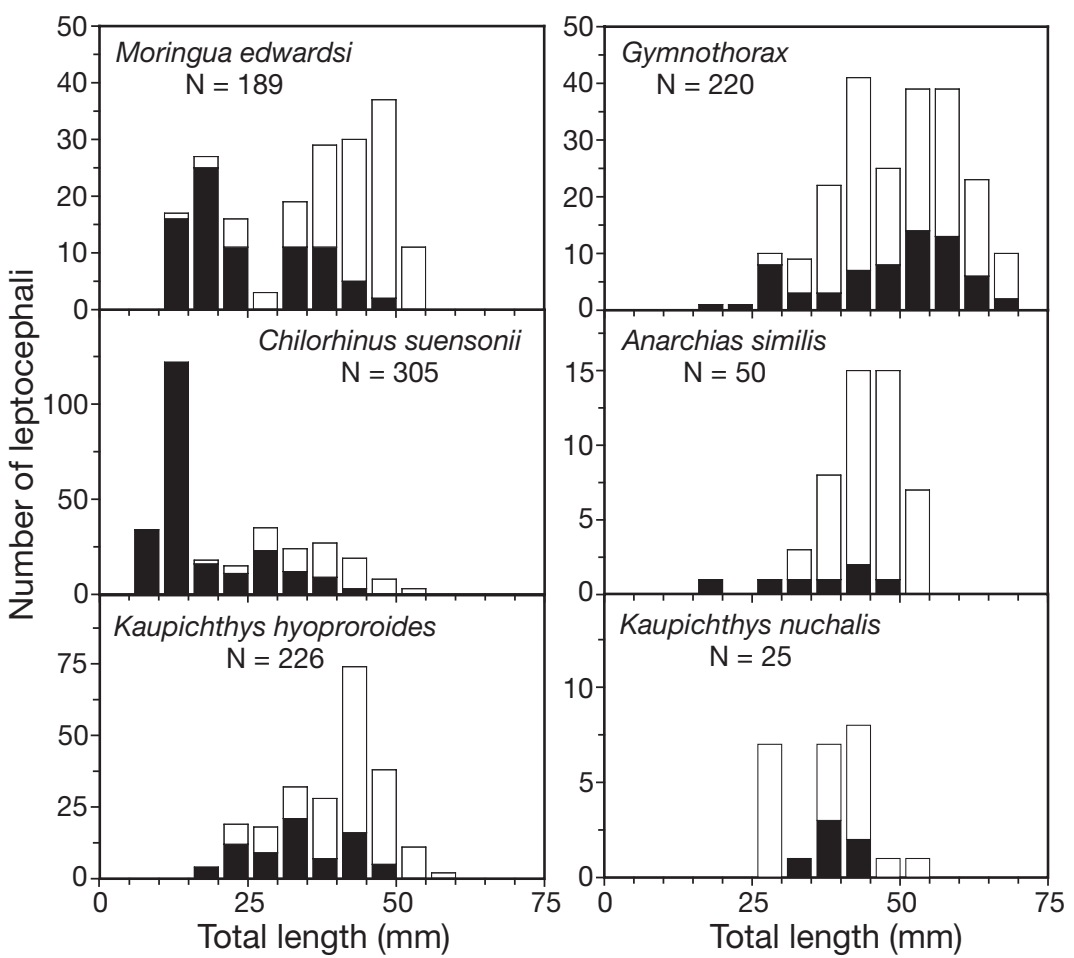

Fig. 4. Moringuidae, Muraenidae, and Chlopsidae. Length frequency distributions of 6 taxa of leptocephali. Leptocephali collected at Stn 12 in the NWPC shown with black bars; those collected at all other stations shown with white bars were collected in the NWPC, where 305 of a wide size range were caught. The 10 to $15 \mathrm{~mm}$ size class was most abundant, but 14 leptocephali $<10 \mathrm{~mm}$ were also collected. There were also a few slightly larger C. suensonii (19 to $25 \mathrm{~mm}$ ) in the FC, and 21 and $24 \mathrm{~mm}$ specimens were caught at Stn 9 offshore in the Sargasso Sea, but they were all $>30 \mathrm{~mm}$ at the rest of the stations. A similar pattern was observed for Moringua edwardsi, but no leptocephali less than $10 \mathrm{~mm}$ were collected in the NWPC (Figs. $4 \& 5$ ). The sizes of the other taxa such as Kaupichthys hyoproroides and several muraenids showed less distinct size differences across areas, but some of the Gymnothorax spp. were considerably smaller in the NWPC than in other areas. The less common moringuid Neoconger mucronatus was large in size and was only collected in the FC and NWPC. In general, the largest minimum sizes of all species of these 3 families were observed at Stns 3 to 5 (Fig. 5).

Ophichthid leptocephali were rare and large in size in offshore areas, and the smallest individuals of most species were collected in the NWPC where ophichthids were most abundant (Figs. 6 \& 7). Ophichthids of 6 species were present in the FC, but 17 of the 22 total species found in this study were not collected offshore at Stns 3 to 11. Ahlia egmontis was the only ophichthid consistently collected far out in the Sargasso Sea $(\mathrm{N}=15$, at 7 offshore stations), but these leptocephali were greater than $30 \mathrm{~mm}$ long. The other abundant species Myrophis punctatus and Ichthyapus ophioneus were each represented by only 3 leptocephali collected offshore. These 2 species were both abundant at a wide range of sizes in the NWPC, but $M$. punctatus also was present at the $2 \mathrm{FC}$ stations, as was Myrophis platyrhynchus. Although the ophichthids collected in the FC were all $>20 \mathrm{~mm}, 6$ of the 20 species in the NWPC had a few specimens of $<20 \mathrm{~mm}$. The majority of other ophichthids were larger in size, with peaks in abundances between 65 and $75 \mathrm{~mm}$ for A. egmontis and between 30 and $40 \mathrm{~mm}$ for $M$. platyrhynchus and $I$. ophioneus (Fig. 6). M. puntatus had a more bimodal length frequency distribution than the other species in the NWPC. 
Although many of the same taxa were found at both the NWPC and FC stations, there were some differences observed in the species composition and size ranges at Stns 1 and 2 in the FC. The congrid taxa Bathycongrus, Gnathophis, and Uroconger were each collected at Stn 2, but were absent from Stn 1 (Fig. 3). In contrast, Ahlia egmontis was present at
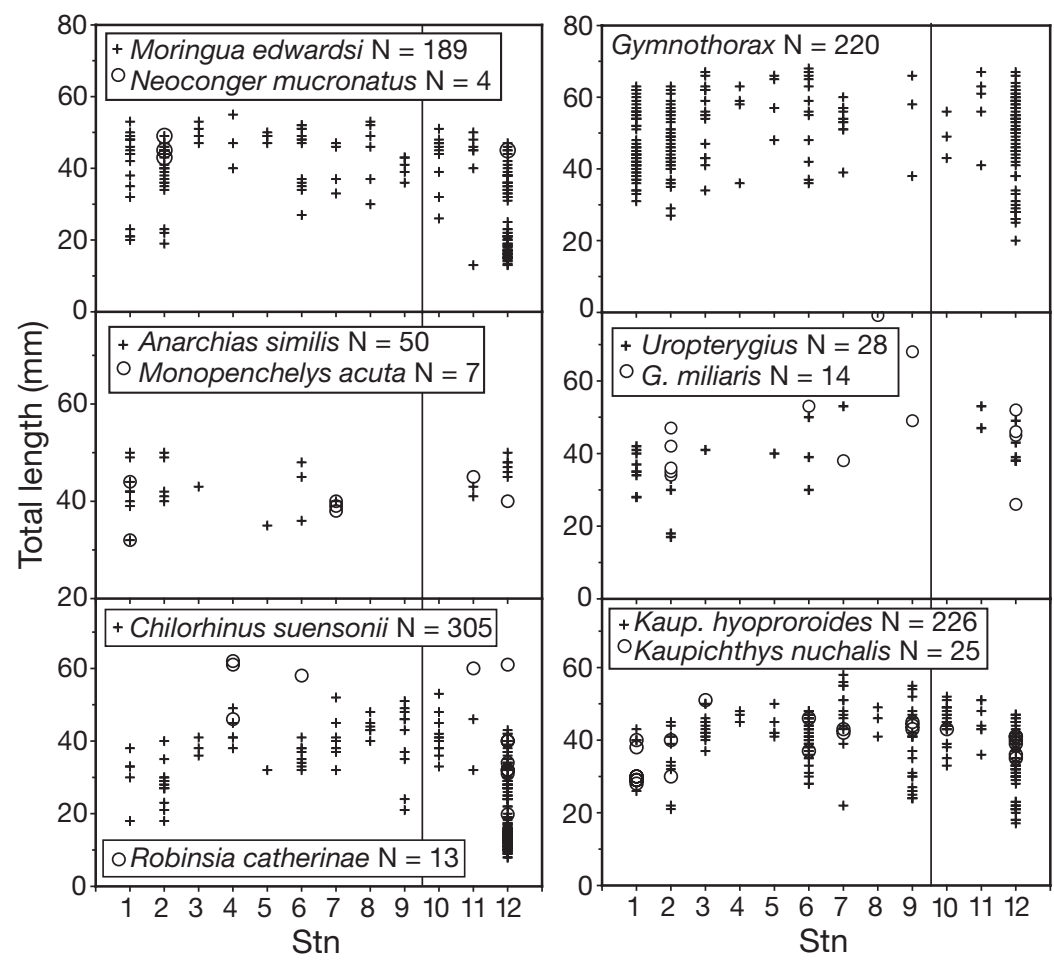

Fig. 5. Moringuidae, Muraenidae, and Chlopsidae. Lengths of individual leptocephali of the most abundant taxa collected at each station in the Sargasso Sea
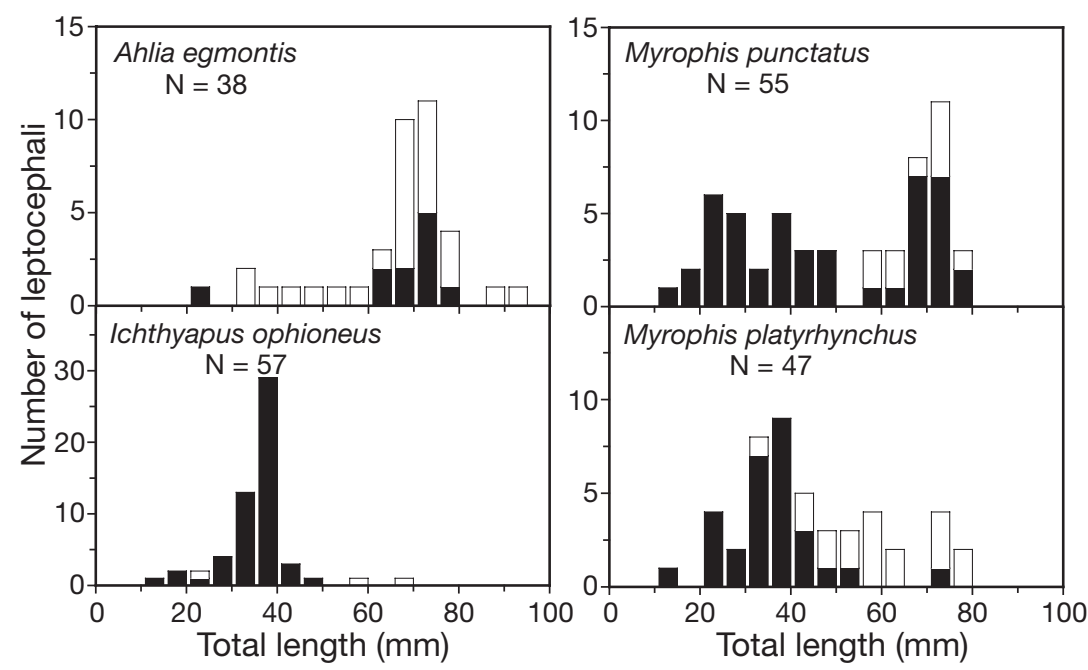

Fig. 6. Ophichthidae. Length frequency distributions of 4 species of leptocephali collected at Stn 12 in the NWPC shown with black bars; those collected at all other stations shown with white bars
Stn 1 but absent from Stn 2 (Fig. 7). Various other species were present at both stations, and had overlapping but usually differing size ranges. The sizes of Paraconger spp. were significantly different between the 2 stations ( $U$-test, $\mathrm{p}<0.001$ ), with the mean length at Stn $1(39.4 \pm 11.8 \mathrm{~mm})$ being lower than that at Stn $2(49.1 \pm 10.7 \mathrm{~mm})$. The sizes of the other 2 most abundant species in the FC, Gymnothorax ( $t$-test, $\mathrm{p}=0.9$ ) and Moringua edwardsi ( $U$-test, $\mathrm{p}=0.43$ ), were not significantly different.

The lengths of Moringua edwardsi and Chilorhinus suensonii leptocephali each differed significantly among regions (Kruskal-Wallis, $\mathrm{p}<0.001$ ), but the only differences were between the NWPC and the other 3 locations (FC, Sargasso Sea, off Abaco) (Fig. 5). Lengths of Gymnothorax spp. leptocephali were significantly different among the 3 areas tested (FC, Sargasso Sea, NWPC) (ANOVA, p < 0.001), with those in the Sargasso Sea differing from those in both the FC and NWPC. Kaupichthys hyoproroides lengths differed among the 4 regions (Kruskal-Wallis, p < 0.001), with Stns 10 and 11 off Abaco differing from the FC and NWPC, and the Sargasso Sea differing from the NWPC.

\section{Catch rates of leptocephali}

The plots of catch rates of the major taxa at each station showed several clear patterns of distribution and abundance in the study area. These catch rates were based on both replicate tows at each station, and the differences in the total catch rates of all leptocephali of the 5 families between the 2 replicate tows at each station varied from $0.69 \%$ at Stn 12 to $43.6 \%$ at Stn 3, with a mean percent difference of $16.1 \pm$ 13.4 ind. $/ 10^{5} \mathrm{~m}^{3}$. Ariosoma balearicum was distinctly most abundant at Stn 12 in the NWPC, but unlike other taxa, it also had high catch rates offshore (Fig. 8). Its catch rate at Stn 12 (415 ind. $/ 10^{5} \mathrm{~m}^{3}$ ) was higher than that of other taxa at any station, but Chilorhinus suensonii (131 ind./ $10^{5} \mathrm{~m}^{3}$ ), Moringua edwardsi (46 ind./ $10^{5} \mathrm{~m}^{3}$ ), and 21 ophichthids (100 ind./ $10^{5} \mathrm{~m}^{3}$ ) were markedly more abundant there also (Fig. 9). The catch rate pattern of the latter group of ophichthid species was similar to that of the congrid genera 

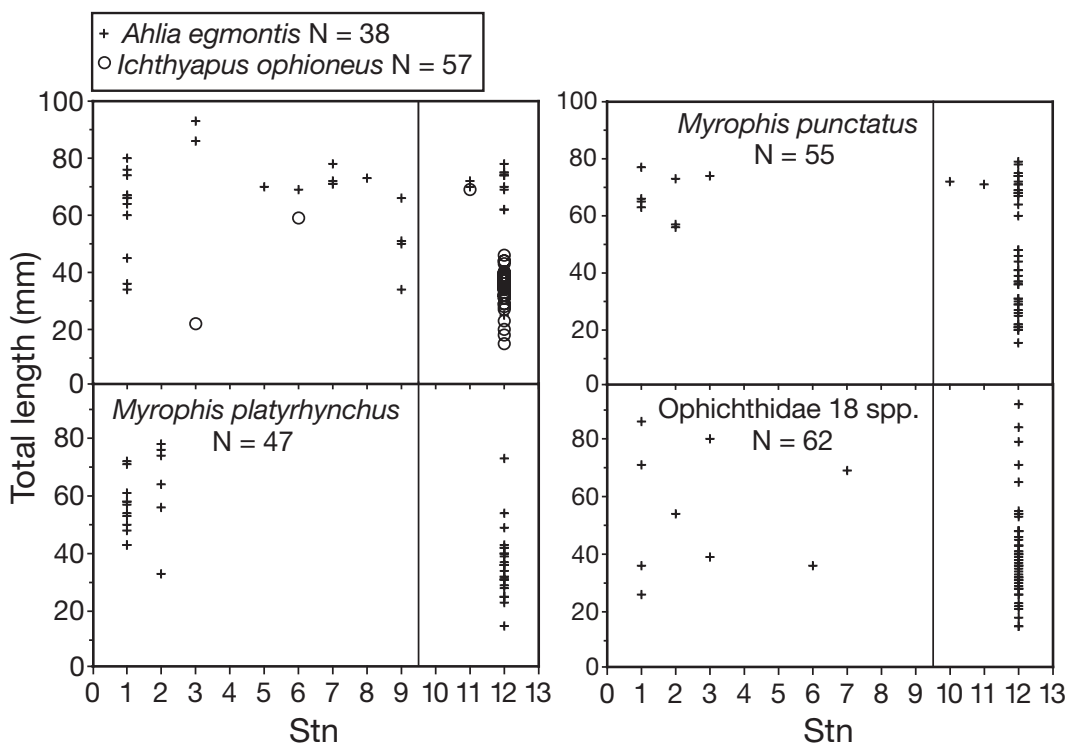

Fig. 7. Ophichthidae. Lengths of individual leptocephali of 18 species collected at each station in the Sargasso Sea

Heteroconger and Paraconger because they were almost completely absent from offshore areas outside of the NWPC and FC. Muraenid leptocephali also showed the highest catch rates in these 2 areas, but they also had some moderately high catch rates offshore, as did Kaupichthys hyoproroides (Fig. 9). Other taxa such as Conger oceanicus, Gnathophis spp., Ahlia egmontis, and Xenomystax congroides showed similarly low catch rates in most of the areas in which they were collected (Figs. $8 \& 9$ ).
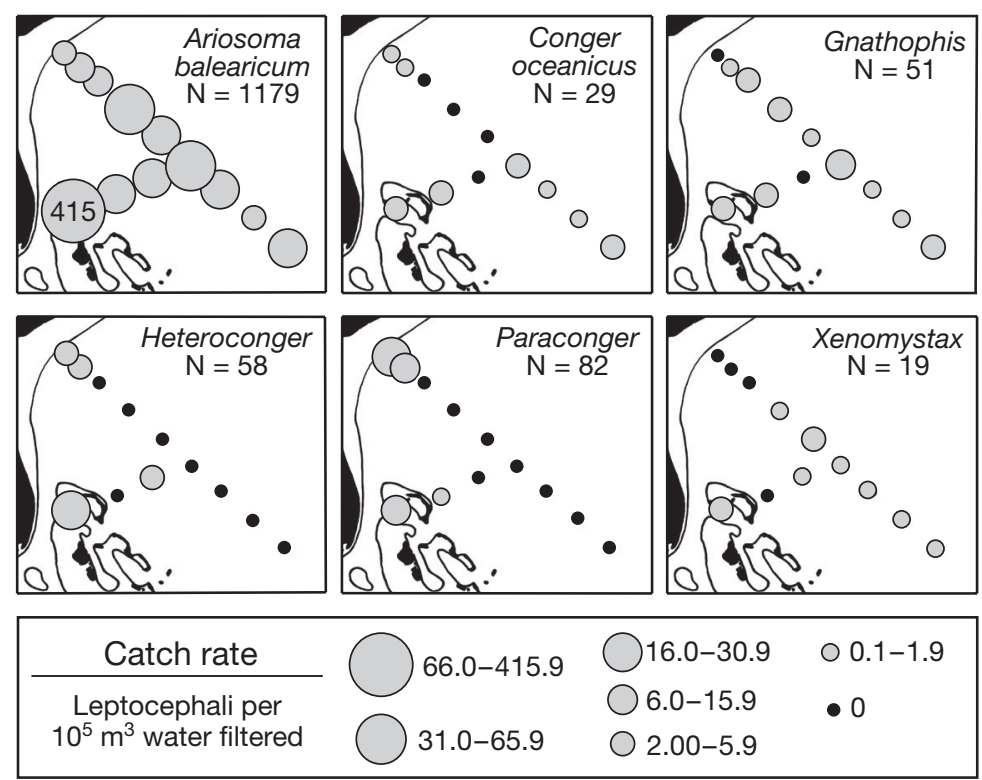

Fig. 8. Congridae. Catch rates of leptocephali collected at each station in the Sargasso Sea

\section{Assemblages of leptocephali}

The cluster analysis and ordination showed that there were some clear geographic differences in the assemblages of 26 taxa of the 5 families of shelf and slope leptocephali, but that the assemblages at most of the offshore stations were not distinctly different. The stations in the dendrogram were separated into 3 major clusters and 1 individual station that were arbitrarily designated as cluster groups $\mathrm{A}_{\text {, }}$ B, C (Fig. 10, upper left panel). Stns 1 and 2 in the FC and Stn 12 in the NWPC clustered together in Group A, probably due to the high catch rates of many species there and the presence of the variety of taxa that were absent offshore. This group formed 1 of the 2 major branches in the dendrogram, with the other branch being separated into 3 branches. Stn 8 did not cluster with other stations, apparently because of a lack of muraenids (with the exception of 2 rare species), and it was the only station that contained only 2 species of chlopsids, which were the 2 abundant species that were collected at every station. Group B was a mixture of 3 stations at the southeast end of the offshore transect, Stn 11 off Abaco, and Stn 3 close to the Florida Current. Group C consisted of Stns 4, 5, 10, which were located close to each other in the west-central region of the study area. The dissimilarity scale showed that Groups B and C were not very different.

The MDS showed that the 3 designated cluster groups could be contained within non-overlapping ovals, but supported the suggestion that Groups B and C were not distinctly different (Fig. 10, lower left panel). The stations in the FC and NWPC of Group A were more separated from Group B than was Group C. For example, Stns 4 and 5 of Group C were closer to some of the stations of Group B than they were to Stn 10 of Group C.

SIMPER analysis showed that the pattern of assemblage structure identified by cluster analysis and MDS mostly reflected the distribution and abundance of fewer than 14 species (Table 2). The percent contributions to the within-group affinities of the stations in cluster Group A (FC and NWPC) that were greater than $4 \%$ included Gymnothorax moringa (9.2\%), Moringua edwardsi $(8.6 \%)$, Paraconger spp. (8.4\%), Myrophis platyrhynchus (6.4\%), and 5 other species. Group B had only 


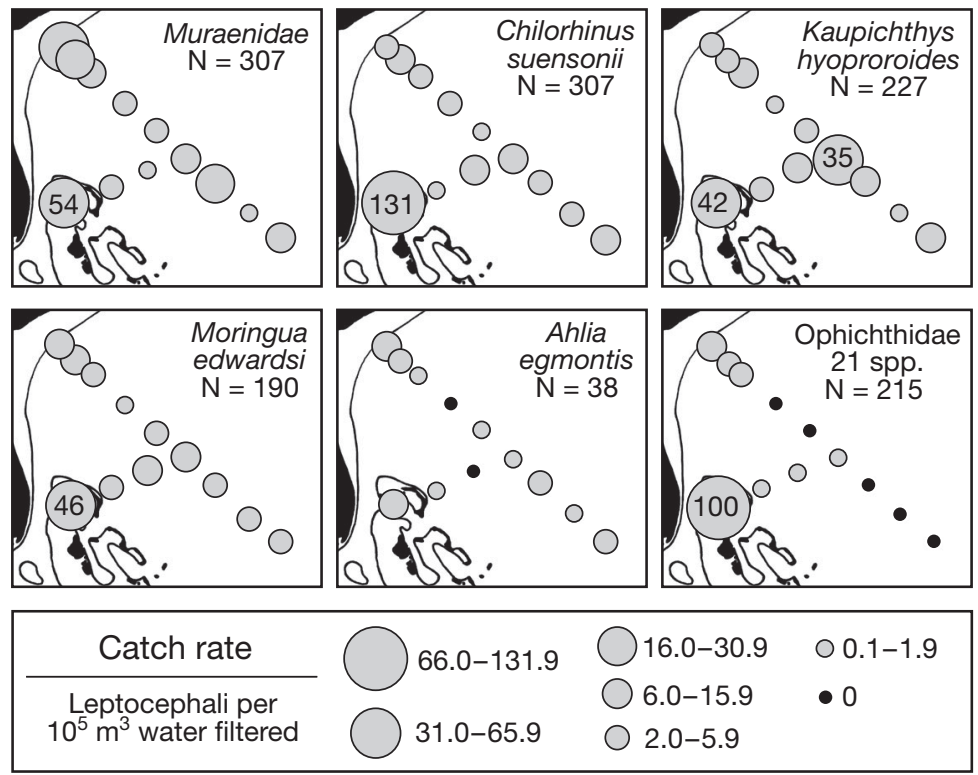

Fig. 9. Chlopsidae, Moringuidae, Muraenidae, and Ophichthidae. Catch rates of various taxa of leptocephali collected at each station in the Sargasso Sea

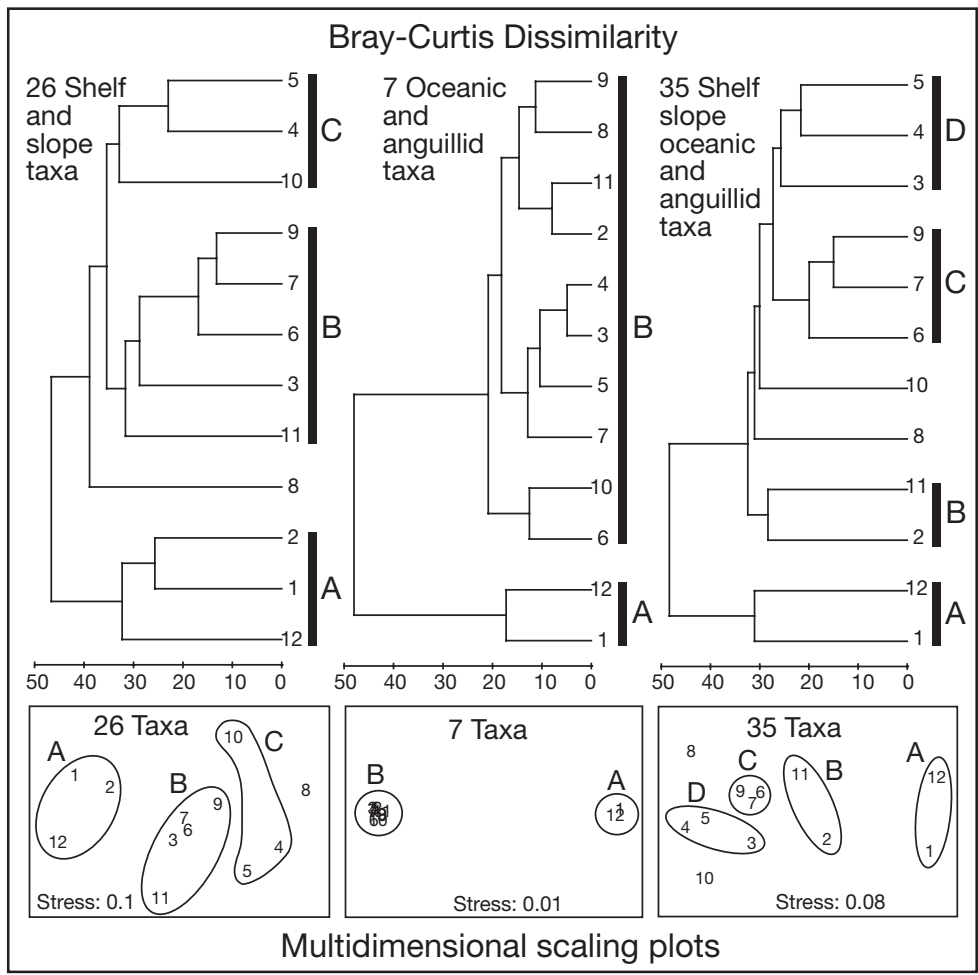

Fig. 10. Dendrograms and MDS plots from cluster analyses and ordination of the catch rates of leptocephali at 12 stations, including 26 taxa of the Chlopsidae, Congridae, Moringuidae, Muraenidae, and Ophichthidae from this study (left), 7 species of anguillid and oceanic taxa from previous studies of the same sampling survey (middle), and 35 taxa including those of the first 2 analyses in addition to 2 slope species (right). Designated cluster groups are indicated with thick black lines in the dendrograms, and stations of these groups are enclosed in ovals in the MDS plots
6 species that exceeded $4 \%$ contribution, with Ariosoma balearicum (13.8\%), Kaupichthys hyoproroides $(11.0 \%)$, and $M$. edwardsi (8.8\%) having the greatest influence. A. balearicum $(24.2 \%)$ made the greatest contribution to Group C, with $K$. hyoproroides $(12.5 \%)$, and $M$. edwardsi $(12.2 \%)$ and Anarchias similis (11.2\%) making smaller contributions.

The number of species of leptocephali collected at each station varied considerably, with the greatest numbers of species being collected along the margins of the study area (Table 1 \& Fig. 11, upper panel). There were 46 species collected in the NWPC, which included at least 20 ophichthids. There were 24 species collected at Stn 2, including only 3 ophichthids, but 9 congrids. Fewer species were collected at Stn 1 (21), and 10 to 20 species were collected offshore. Stns 6, 7, 11 comprised the highest numbers of species offshore (18 to 20). The 2 methods of calculating species diversity $\left(H^{\prime}\right.$ and $\left.\operatorname{Exp} H^{\prime}\right)$ both revealed that the 2 stations in the $\mathrm{FC}$ had the greatest diversity. More species were collected at Stn 12 in the NWPC, but $H^{\prime}$ and $\operatorname{Exp} H^{\prime}$ were lower because the overall abundance of leptocephali was dominated by a few species, such as Ariosoma balearicum, Chilorhinus suensonii, Kaupichthys hyoproroides and Moringua edwardsi, which comprised $71.5 \%$ of the individuals of the 46 species collected there (Table 1).

The catch rates of 9 species of 6 other families collected during this survey (Fig. 11, lower panel) were also used in additional cluster analyses and ordinations of the assemblages of leptocephali at each station for comparison with the patterns of distribution and abundance of the 5 families of shelf and upper slope eels. These were the leptocephali of the catadromous anguillid eels Anguilla rostrata and $A$. anguilla (McCleave \& Kleckner 1987), the mesopelagic (oceanic) species Derichthys serpentinus, Nessorhamphus ingolfianus (Castonguay \& McCleave 1987a), Nemichthys scolopaceus and Labichthys carinatus (Wippelhauser et al. 1996), Serrivomer brevidentatus, and the outer shelf and slope species of Nettastoma sp. and Nettenchelys pigmaea (M. Miller \& J. McCleave unpubl. data). Single specimens of Hoplunus macrua and Nettenchelys inion/exoria 
Table 2. Number of specimens and overall catch rate (ind. $/ 10^{5} \mathrm{~m}^{3}$ ) of 26 taxa of 5 families of leptocephali in each of the major designated cluster groups in the dendrogram of Fig. 10 (upper left), and the \% contribution (CTB) of typifying taxa to withingroup similarities of each of the 4 cluster groups as indicated by SIMPER analysis. Only taxa contributing over $4 \%$ are shown. No CTB values were calculated for Stn 8 because it did not group with other stations

\begin{tabular}{|c|c|c|c|c|c|c|c|c|c|}
\hline \multirow[t]{2}{*}{ Family } & \multirow{2}{*}{ Taxa } & \multicolumn{2}{|c|}{- Group A- } & \multicolumn{2}{|c|}{ — Group B- } & \multicolumn{2}{|c|}{ - Group C- } & \multicolumn{2}{|c|}{$-\operatorname{Stn} 8-$} \\
\hline & & $\mathrm{N}$ & $\%$ CTB & $\mathrm{N}$ & $\%$ СТВ & $\mathrm{N}$ & $\%$ CTB & $\mathrm{N}$ & $\%$ of total \\
\hline \multirow[t]{5}{*}{ Congridae } & Ariosoma balearicum & 752 & 6.9 & 204 & 13.8 & 213 & 24.2 & 10 & 31.2 \\
\hline & Gnathophis & 8 & & 31 & 8.7 & 10 & & 2 & 6.2 \\
\hline & Heteroconger & 57 & 6.5 & & & 1 & & & \\
\hline & Paraconger & 81 & 8.4 & 1 & & & & & \\
\hline & Xenomystax congroides & & & 5 & & 13 & 11.9 & 1 & 3.1 \\
\hline \multirow[t]{2}{*}{ Chlopsidae } & Chilorhinus suensonii & 253 & 6.7 & 30 & 8.2 & 18 & 10.5 & 6 & 18.7 \\
\hline & Kaupichthys hyoproroides & 88 & 6.0 & 103 & 11.0 & 33 & 12.5 & 3 & 9.4 \\
\hline Moringuidae & Moringua edwardsi & 132 & 8.6 & 33 & 8.8 & 19 & 12.2 & 6 & 18.7 \\
\hline \multirow[t]{3}{*}{ Muraenidae } & Gymnothorax moringa & 107 & 9.2 & 32 & 8.0 & 7 & 9.8 & & \\
\hline & Anarchias similis & 13 & & 27 & & 12 & 11.9 & & \\
\hline & Uropterygius macularius & 9 & 5.8 & 7 & & 1 & & & \\
\hline \multirow[t]{3}{*}{ Ophichthidae } & Ahlia egmontis & 23 & & 13 & 6.8 & 1 & & 1 & 3.1 \\
\hline & Myrophis platyrhynchus & 29 & 6.4 & & & & & & \\
\hline & Myrophis punctatus & 53 & 5.3 & 2 & & 1 & & & \\
\hline Total no. ind. & & 1850 & & 556 & & 337 & & 32 & \\
\hline No. tows & & 6 & & 10 & & 6 & & 2 & \\
\hline Total catch rate & & 353.0 & & 78.6 & & 48.1 & & 17.4 & \\
\hline
\end{tabular}

at Stn 5 (Nettastomatidae), Dysomma anguillare and another synaphobranchid (Stns 4 and 5, respectively), and 2 Serrivomer beanii (Stns 10, 11) were also collected during the survey, along with 2 Albula vulpes (Albuliformes) and 1 Elops saurus (Elopiformes) in the $\mathrm{FC}$, but these taxa were not included in the analysis due to their rarity.

An analysis of the 2 anguillid and 5 oceanic species showed that there were only 2 distinctly different assemblages of these species, which all spawn offshore in the Sargasso Sea (Fig. 10, upper middle panel). Stns 1 and 12 formed 1 distinct cluster because of the absence or low catch rates of most of these species there. Of these 7 species, only Anguilla rostrata and Nemichthys scolopaceus were collected at Stn 1 in the FC, and of the 5 oceanic species, only N. scolopaceus was collected at Stn 12 in the NWPC (Fig. 11). The MDS plot of this 7-species analysis showed that there were only minor differences among Stns 2 to 11 , because all but 1 of the species were present at all the offshore stations. The 35-taxa analysis included the 26 taxa of the 5 families, the 7 taxa of the second analysis, and 2 species of leptocephali of the outer shelf and slope eels of the Nettastomatidae: Nettenchelys pygmaea $(\mathrm{N}=9$, Stns $2,5,7,9)$, and Nettastoma sp. $(\mathrm{N}=7$, Stns $3,6,8)$. This analysis found clusters that included Stns 1 and 12 (Group A), Stns 2 and 11 (Group B), and 2 other clusters (Group C: Stns 6, 7, 9; Group D: Stns 3, $4,5)$, with Stns 8 and 10 not forming clusters with other stations (Fig. 10, upper right panel).

\section{DISCUSSION}

\section{Assemblages of leptocephali in the Sargasso Sea region}

At least 62 species of leptocephali of the 5 families that were the focus of this study were collected in the Sargasso Sea during late September and October of 1984, and there were distinct differences in the assemblages between the marginal and offshore areas of the region. The leptocephali of some species of the Chlopsidae, Congridae, Moringuidae and Muraenidae were widespread throughout the region, but there were distinctly different assemblages of these families at the stations along the margins of the Sargasso Sea. Higher catch rates of some taxa and more species were present in the FC and NWPC than offshore. The congrid genera Heteroconger and Paraconger were collected almost exclusively in the FC and NWPC. Another interesting finding was that there were many ophichthid species that were only collected in the NWPC, and a few others were only collected within or near the FC (Table 1). This suggests that there is a high biodiversity of marine eels that live on the large banks of the Northern Bahamas.

The distinct patterns of distribution and abundance of leptocephali in the FC and NWPC appeared to be the major factors affecting the multivariate analyses. The importance of Heteroconger spp., Paraconger spp. and ophichthids in the formation of Group A in the 

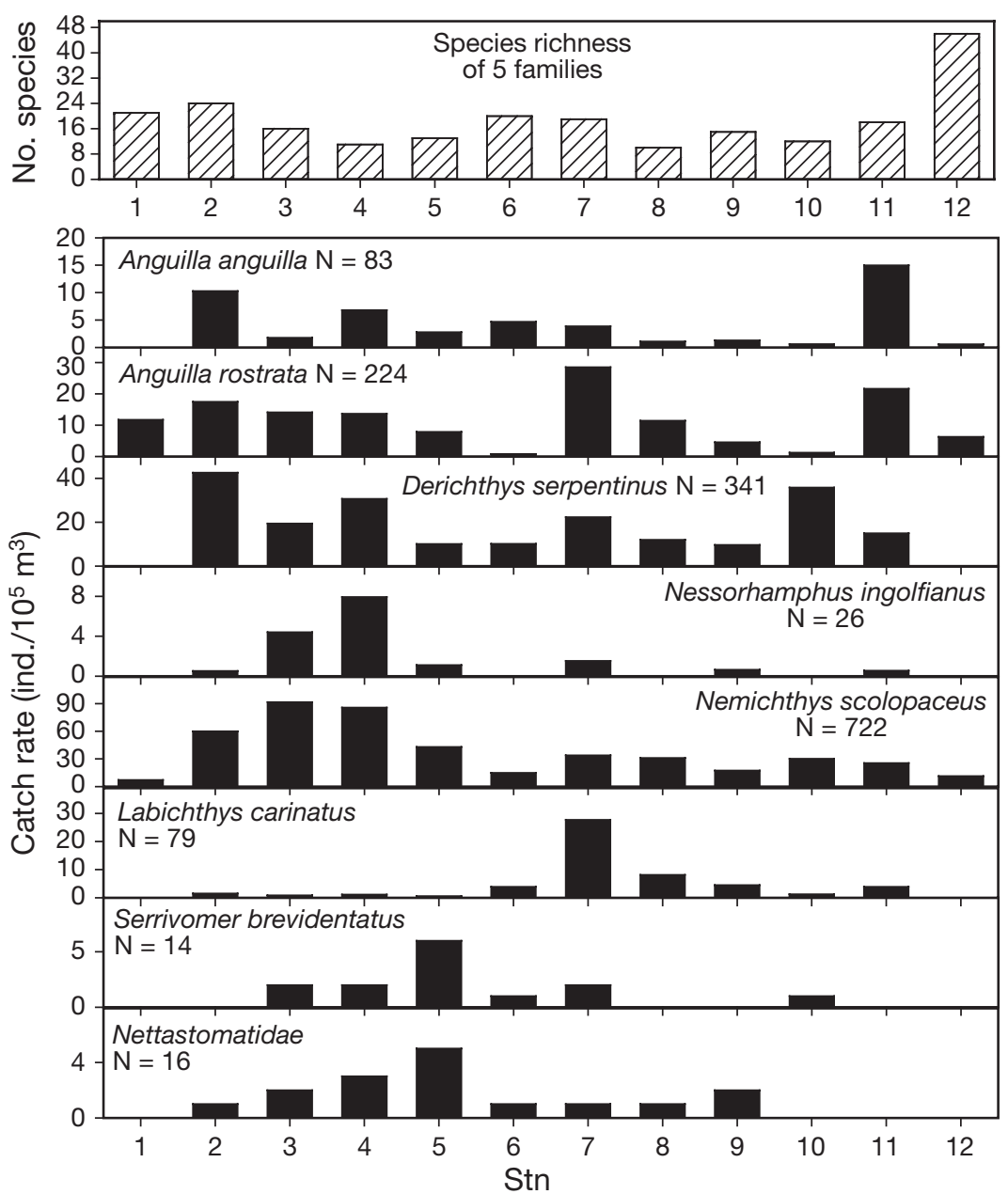

Fig. 11. Chlopsidae, Congridae, Moringuidae, Muraenidae, and Ophichthidae. Number of species of leptocephali collected at each station of this study (top panel), and catch rates of 2 species of leptocephali of the genus Anguilla (catadromous eels), 5 species of mesopelagic eels, and 2 species of outer shelf and slope eels (Nettastomatidae) collected during the same sampling survey of this study

26-taxa dendrogram (Fig. 10, upper left panel) was demonstrated by the SIMPER analysis, and could be seen in the catch rate (Fig. 8) and length-station plots (Fig. 3). The NWPC had greater catch rates of some species of all 5 families, including the 4 most abundant species of the study (Ariosoma balearicum, Chilorhinus suensonii, Kaupichthys hyoproroides, Moringua edwardsi), because they appeared to have been spawning somewhere near the Bahama Banks. These factors resulted in the FC and NWPC having distinctly different assemblages in the cluster analysis and MDS compared with offshore stations, even though the 4 most abundant species were collected at every station.

Because the offshore stations comprised fewer species and differed less in species composition among stations, their patterns of clustering likely reflected dif- ferences in the relative abundance of common species and the presence or absence of a few rare species. Conger oceanicus and $C$. triporiceps were both absent from Stns 3, 4, 5, and 10 in the west (Figs. $3 \& 8$ ), so these types of small variations probably resulted in the clustering patterns of the offshore stations. For example, Group C (Fig. 10, upper left panel) included 3 stations that clustered separately possibly due to a lack of leptocephali of Conger spp. and the rare muraenids, Gynmothorax miliaris and Monopenchelys acuta, and the presence of Xenomystax congroides. Stn 8 clustered separately from other stations possibly because of a complete lack of the 4 most abundant muraenids and 4 rare chlopsids.

Different patterns of distribution and regional size ranges compared with those of the present study were observed in previous studies of catadromous and oceanic eel leptocephali collected during this cruise. The larval distributions of the anguillid eels Anguilla rostrata and A. anguilla and several mesopelagic species of the Derichthyidae, Nemichthyidae, and Serrivomeridae would be expected to differ from the species in the present study because they spawn in the offshore areas of the southern Sargasso Sea (Castonguay \& McCleave 1987a, Kleckner \& McCleave 1988, Miller \& McCleave 1994). The leptocephali of $A$. rostrata were collected at all stations of the survey, but they were rare at Stns 6 and 10, and most abundant at Stns 7 and 11 (Fig. 11; McCleave \& Kleckner 1987). The leptocephali of $A$. anguilla were considerably smaller in size, and were rare at Stns $3,8,9,10,12$. In contrast with $A$. rostrata, they were absent from Stn 1 in the FC, and only 1 was collected in the NWPC where a considerable number of large sized A. rostrata were collected (Fig. 11). $A$. anguilla were most abundant at $\operatorname{Stn} 11$, where $A$. rostrata were also abundant. Stn 11 is located just off Abaco Island (Fig. 1) where northwest flow of the Antilles Current is often present (Meinen et al. 2004), and this flow is probably one of the most direct transport routes of anguillid leptocephali out of the Southern Sargasso Sea (McCleave \& Kleckner 1987, McCleave 1993). With the exception of Stns 7 and 11 for $A$. rostrata, all the catch rates of anguillid leptocephali were lower than 20 to 30 ind. $/ 10^{5} \mathrm{~m}^{3}$, and the catch rates of $A$. anguilla were all less than 15 ind./ $10^{5} \mathrm{~m}^{3}$ (Fig. 11), so several species such as Ariosoma 
balearicum and the 2 abundant chlopsid species collected during the present study had similar or higher catch rates in some offshore areas.

The leptocephali of several species of mesopelagic eels of the Derichthyidae and Nemichthyidae were also abundant across the southwest Sargasso Sea during October. Derichthys serpentinus had a distribution that was similar to that of Anguilla anguilla, and it was also absent from Stn 1 and the NWPC (Fig. 11, Castonguay \& McCleave 1987a). The highest catch rates of D. serpentinus were at Stns 2, 4, 10 (about 30 to 43 ind./ $10^{5} \mathrm{~m}^{3}$ ), where 83, 54 and 58 individuals were collected. These rates were higher than those of most species except Ariosoma balearicum in the present study. Abundances varied at the other offshore stations from 13 to 54 leptocephali, with catch rates ranging between about 10 and 22 ind. $/ 10^{5} \mathrm{~m}^{3}$. Nessorhamphus ingolfianus was also present at various stations, but they were only abundant at Stns 3 and 4 (Fig. 11). The leptocephali of these 2 derichthyid species were more abundant during a similar survey conducted earlier in the year, primarily in August (Castonguay \& McCleave 1987a). The catch rates of Nemichthys scolopaceus were highest at Stns 2 to 5, but this species was present in lower numbers at all the other stations (Fig. 11, Wipplehauser et al. 1996). Another nemichthyid species, Labichthys carinatus, was much less abundant, with its highest catch rate at Stn 7, and no individuals being collected from Stns 1 and 12 (Fig. 11). Only a few Serrivomer brevidentatus were collected, mostly offshore in the central part of the study area.

Considering the presence of the leptocephali of the catadromous, oceanic, and shelf species during this survey, a diverse assemblage was present that was similar in many respects to those observed offshore in the late winter and spring (February to April) in other surveys. The same 4 most abundant species of the present study were widely distributed from February to April, as were anguillids (Schoth \& Tesch 1982, Kleckner \& McCleave 1988, Miller \& McCleave 1994). The abundant shelf species were of similarly large sizes in the offshore areas, but the sizes of the anguillid leptocephali were much smaller because the February to April period is within their spawning season (Kleckner \& McCleave 1988). Other differences between the 2 seasons were that the leptocephali of the 2 species of Serrivomer and those of Eurypharynx pelecanoides were much more abundant from February to April than during the summer and fall seasons, but derichthyids were absent between February and April (Miller \& McCleave 1994). Only about 30 species were collected between February and April, which did not include most of the congrids and ophichthids that were restricted to the NWPC and FC in the present study.
The patterns of assemblage structure of the $>77$ species of 13 families observed in the Sargasso Sea region in this study were somewhat different from those observed in studies on leptocephali in other parts of the Atlantic and in the Indo-Pacific. At least 63 species were collected over several years near the western edge of the Gulf Stream off North Carolina, with only 9 taxa of congrids, muraenids and ophichthids accounting for $70 \%$ of the catches (Ross et al. 2007). The assemblage of leptocephali in this region was similar to that to the southwest at Stn 1 in the present study, because Paraconger and Gymnothorax were the most abundant genera in both areas. Only 20 species of leptocephali were collected in the eastern Gulf of Mexico in offshore sampling near the edge of the continental shelf (Crabtree et al. 1992). An assemblage of 68 species was collected to the southeast of the Sargasso Sea during many surveys conducted near Barbados (Richardson \& Cowen 2004). In the South Atlantic, about 83 species were present in collections of more than 10000 leptocephali made over about $10 \mathrm{yr}$ in the Gulf of Guinea of East Africa, but anguillids are not present in the South Atlantic and few oceanic leptocephali were described (Blache 1977). In the IndoPacific, at least 45 species of leptocephali were collected during a survey over the outer shelf and slope along the boundary between the Kuroshio and East China Sea to the south of Japan, with single species of Gnathophis and Dysomma (Synaphobranchinae) being abundant as a result of recent spawning activity (Miller et al. 2002). Higher species richness was observed in the western South Pacific, where more than 90 species of leptocephali were collected in offshore areas, but the relative abundances of various taxa such congrids, chlopsids and serrivomerids differed from those observed in the present study (Miller et al. 2006). Even higher species richness of leptocephali (>136 species) was observed around Sulawesi Island of Indonesia, as would be expected based on general patterns of fish biodiversity (Wouthuyzen et al. 2005).

\section{Life history and larval transport}

The distribution and size of leptocephali during the present study provided new information about the possible spawning locations of a variety of marine eels in the region because there was a well-defined distribution of their recently spawned leptocephali. Various species of congrids and ophichthids were collected only in the NWPC or FC, and most abundant taxa were collected in the NWPC at smaller sizes and at much greater catch rates than offshore. The smaller sizes, greater abundances and higher species richness in the NWPC indicated that many marine eels had spawned within the 
Northern Bahamas without migrating far offshore. Many species of ophichthids, moringuids, and some congrids burrow in sandy or muddy sediments, while other species of muraenids and chlopsids occur in association with coral reefs or sea grass beds (Böhlke 1989a), so the Bahama Banks likely provide these habitats for eels.

The exact spawning locations of these eels cannot be determined from the present study, but previous observations suggest that some may spawn over the banks, near the edge of the shelf break, or over adjacent deeper water. Some species of moray eels and garden eels may spawn in their shallow water habitats (Moyer \& Zaiser 1982, Thresher 1984, Ferraris 1985), and garden eels likely spawn within their colonies (Thresher 1984). One ophichthid species was observed migrating over the continental shelf to spawn somewhere in deeper water (Cohen \& Dean 1970), and other species have been observed at the surface over the shelf at night (Ross \& Rohde 2003). These observations and catches of their leptocephali over continental shelves (Fahay \& Obenchain 1978, Miller et al. 2002, Ross et al. 2007) indicate that many ophichthids spawn over the continental shelf or near its edge. Evidence of spawning of various marine eels was recently seen along the edge of the continental shelf in the East China Sea during a survey for leptocephali (Miller et al. 2002), and some congrids such as those of the genus Gnathophis. may spawn over the outer shelf in many temperate and subtropical areas (Miller et al. 2002, Kimura et al. 2006). The 8 to $15 \mathrm{~mm}$ minimum sizes of leptocephali of 9 species at Stn 12 in the NWPC (water depth $\sim 600 \mathrm{~m}$ ) were consistent with spawning having occurred somewhere near the edge of the banks.

The larval distributions and sizes and assemblage analyses provided information about the possible dispersal patterns of leptocephali in the region. Surface water flows in both directions through parts of the NWPC (Leaman \& Molinari 1987, Johns et al. 1999), so some leptocephali could be transported westward from the NWPC into the eastern edge of the FC and then northward. The differences among the species or size ranges of some congrids at the $2 \mathrm{FC}$ stations suggested that Stn 1 could have included leptocephali originating from the Gulf of Mexico or Florida Keys, as was suggested in previous studies (Miller 1995, Ross et al. 2007). Some of these leptocephali moving northward in the FC could be transported into the western Sargasso Sea by Gulf Stream cold-core rings, or eddies or intrusions of water from the FC or Gulf Stream (Vukovich \& Crissman 1978, Richardson 1983, Cornillon et al. 1986). Others could enter the water recirculated southeast into the Sargasso Sea north of Bermuda (Marchese 1999). The presence of a variety of large sized leptocephali of these 5 families near Bermuda (Keller 1976, Miller 2002a) supports this hypothesis.
Farther to the south, anguillid eels spawn offshore in the winter and spring (Kleckner \& McCleave 1988), as do oceanic eels (Castonguay \& McCleave 1987a, Miller \& McCleave 1994, Smith \& Miller 1996, Wippelhauser et al. 1996), but there is no evidence of offshore spawning by shelf eels other than Conger oceanicus in the southern Sargasso Sea (McCleave \& Miller 1994) and possibly some Ariosoma balearicum east of the FC (Miller 2002a). This raises the question of how some species that do not migrate offshore to spawn become so widely distributed across the southwest Sargasso Sea. In addition to Gulf Stream recirculation, some leptocephali could be transported eastward into the Sargasso Sea by the frontal jets present in the STCZ from late autumn until spring (Eriksen et al. 1991). Two or 3 bands of fronts form there, and because water converges into the fronts on both sides, many leptocephali likely become entrained and transported eastward (Miller \& McCleave 1994). In late summer, these fronts dissipate as surface waters warm throughout the Sargasso Sea, so those leptocephali transported offshore would likely become widespread, as was observed in the present study and a previous survey conducted in August 1984 (M. Miller \& J. McCleave unpubl. data).

During autumn there is often an anticyclonic circulation cell present to the northeast of the Northern Bahamas. The northwest flow typically observed off Abaco Island (Hacker et al. 1996, Meinen et al. 2004) may be part of that large cell (Olson et al. 1984). This flow could transport some leptocephali from the northeastern edge of the Bahamas into offshore areas. The smaller sizes of Chilorinus suensonii and Kaupichthys hyoproroides and the slightly higher species richness at Stns 6 and 7 provide some support for this possibility. Regardless of the exact mechanisms, present knowledge of the spawning locations of most shallow water eel species, the size distributions recorded during this study, and studies conducted during the winter and spring season in the Sargasso Sea (Miller \& McCleave 1994, Miller 1995) indicate that large numbers of leptocephali are transported offshore in the region. However, regional assemblage comparisons indicate that not all species appear to be transported offshore as much as others. It is presently unclear how some species may avoid offshore transport more than others, or whether many of the individuals that are transported offshore eventually recruit to their coastal habitats.

\section{Recruitment mechanisms of leptocephali}

Although the eventual recruitment success of leptocephali in offshore areas is unknown, leptocephali that remain closer to the Northern Bahamas may have a 
better chance to recruit to the various banks in the region. Because spawning by most shelf species occurs close to the banks, many leptocephali may remain close by, as was suggested by the much higher densities of leptocephali in the NWPC. Circumstantial evidence that many leptocephali stay close to the banks and then recruit there derives from studies on the recruitment of fish larvae to Lee Stocking Island, on the Great Bahama Bank adjacent to Exuma Sound (Fig. 1). These studies used floating channel nets to collect fish larvae moving onto the banks with the tide (Shenker et al. 1993). Large numbers of leptocephali of especially the Congridae and Ophichthidae were collected, which were apparently being transported onto the shelf primarily during flood tides (Thorrold et al. 1994). Similar studies using set nets also collected leptocephali as they recruited onto fringing reefs in the Indo-Pacific region (Dufour et al. 1996, McIlwain 2003).

The abundance of leptocephali observed in the NWPC suggests there may be high densities in other areas around the Bahama Banks, and studies of larval fish recruitment suggest that many leptocephali successfully recruit to the banks (Thorrold et al. 1994). It is not known whether or not leptocephali actively swim toward the banks. Other species of fish larvae appear to have the capability to swim actively to their recruitment areas (Leis 2002), so it is also possible that leptocephali can. They are larger than typical fish larvae, and preliminary observations suggest that they are good swimmers (Miller \& Tsukamoto 2004). It is possible that there are a variety of larval dispersal and recruitment strategies used by eels, as was suggested by various studies on catadromous and marine eel leptocephali (McCleave 1993, Miller 2002a,b, Tsukamoto et al. 2002). Future studies on the distribution of leptocephali from hatching to their recruitment to shallow water areas are needed in order to determine whether leptocephali use behavioral mechanisms such as vertical or horizontal swimming to facilitate their recruitment.

Acknowledgements. We thank M. Castonguay, L. Castonguay, R. Kleckner, and E. Turner for assistance with sampling for leptocephali. Collection of the data was supported in part by the Center for Marine Studies, the Migratory Fish Research Institute, and the Department of Oceanography, University of Maine. The University of Maine collections made during this cruise were funded by National Science Foundation Grant OCE-8208394 to J.D.M.

\section{LITERATURE CITED}

Blache J (1977) Leptocephales des poissons Anguilliformes dans la zone sud du Golfe de Guinée. Faune Tropicale 10: $1-381$

Böhlke EB (1989a) Orders Anguilliformes and Saccopharyngiformes. Fishes of the Western North Atlantic. Mem Sears Found Mar Res 1(9):1-655
Böhlke EB (1989b) Leptocephali. Fishes of the Western North Atlantic. Mem Sears Found Mar Res 1(9):657-1055

Castle PHJ (1979) Early life-history of the eel Moringua edwardsi (Pisces, Moringuidae) in the western North Atlantic. Bull Mar Sci 29:1-18

Castonguay LD, McCleave JD (1987a) Distribution of leptocephali of the oceanic species Derichthys serpentinus and Nessorhamphus ingolfianus (Family Derichthyidae) in the western Sargasso Sea in relation to physical oceanography. Bull Mar Sci 41:807-821

Castonguay M, McCleave JD (1987b) Vertical distributions, diel and ontogenetic vertical migrations and net avoidance of leptocephali of Anguilla and other common species in the Sargasso Sea. J Plankton Res 9:195-214

Clarke KR, Warwick RM (1994) Changes in marine communities: an approach to statistical analysis and interpretation. Natural Environment Research Council, Swindon

Cohen DM, Dean D (1970) Sexual maturity and migratory behaviour of the tropical eel, Ahlia egmontis. Nature 227: 189-190

Cornillon P, Evans D, Large W (1986) Warm outbreaks of the Gulf Stream into the Sargasso Sea. J Geophys Res 91: 6583-6596

Crabtree RE, Cyr EC, Bishop RE, Falkenstein LM, Dean JM (1992) Age and growth of tarpon, Megalops atlanticus, larvae in the eastern Gulf of Mexico, with notes on relative abundance and probable spawning areas. Environ Biol Fish 35:361-370

Dufour V, Riclet E, Lo-Yat A (1996) Colonization of reef fishes at Moorea Island, French Polynesia: temporal and spatial variation of the larval flux. Mar Freshw Res 47:413-422

Eriksen CC, Weller RA, Rudnick DL, Pollard RT, Regier LA (1991) Ocean frontal variability in the Frontal Air-Sea Interaction Experiment. J Geophys Res 96:8569-8591

Fahay MP, Obenchain CL (1978) Leptocephali of the ophichthid genera Ahlia, Myrophis, Ophichthus, Pisodonophis, Callechelys, Letharchus, and Apterichtus on the Atlantic continental shelf of the United States. Bull Mar Sci 28:442-486

Ferraris CJ (1985) Redescription and spawning behavior of the muraenid eel Gymnothorax herrei. Copeia 1985:518-520

Field JG, Clarke KR, Warwick RM (1982) A practical strategy for analyzing multispecies distribution patterns. Mar Ecol Prog Ser 8:37-52

Hacker P, Firing E, Wilson WD, Molinari R (1996) Direct observations of the current structure east of the Bahamas. Geophys Res Lett 23:1127-1130

Halliwell GR Jr, Cornillon P, Brink KH, Pollard RT, Evans DL, Regier LA, Toole JM, Schmitt RW (1991) Descriptive oceanography during the Frontal Air-Sea Interaction Experiment: medium- to large-scale variability. J Geophys Res 96:8553-8567

Johns E, WD Wilson, RL Molinari (1999) Direct observations of velocity and transport in the passages between the Intra-Americas Sea and the Atlantic Ocean 1984-1996. J Geophys Res 104:25,805-25,820

Keller A (1976) Systematics, vertical distribution, and life history of anguilliform leptocephali in the Bermuda Ocean Acre. MSc thesis, University of Rhode Island, Kingston

Kimura Y, Miller MJ, Minagawa G, Watanabe S, Shinoda A, Aoyama J, Tsukamoto K (2006) Evidence of a local spawning site of marine eels along northeastern Japan, based on the distribution of small leptocephali. Fish Oceanogr 15: $183-190$

Kleckner RC, McCleave JD (1982) Entry of migrating American eel leptocephali into the Gulf Stream system. Helgol Meeresunters 35:329-339 
Kleckner RC, McCleave JD (1988) The northern limit of spawning by Atlantic eels (Anguilla spp.) in the Sargasso Sea in relation to thermal fronts and surface water masses. J Mar Res 46:647-667

Leaman KD, Molinari RL (1987) Topographic modification of the Florida Current by Little Bahama and Great Bahama Banks. J Phys Oceanogr 17:1724-1736

Leiby MM (1989) Family Ophichthidae: Leptocephali. In: Böhlke EB (ed) Fishes of the Western North Atlantic. Mem Sears Found Mar Res 1(9):764-897

Leis JM (2002) Pacific coral-reef fishes: the implications of behaviour and ecology of larvae for biodiversity and conservation, and a reassessment of the open population paradigm. Environ Biol Fish 65:199-208

Marchese PJ (1999) Variability in the Gulf Stream recirculation gyre. J Geophys Res 104:29549-29560

McCleave JD (1993) Physical and behavioural controls on the oceanic distribution and migration of leptocephali. J Fish Biol 43(Suppl A):243-273

McCleave JD, Kleckner RC (1987) Distribution of leptocephali of the catadromous Anguilla species in the western Sargasso Sea in relation to water circulation and migration. Bull Mar Sci 41:789-806

McCleave JD, Miller MJ (1994) Spawning of Conger oceanicus and Conger triporiceps (Congridae) in the Sargasso Sea and subsequent distribution of leptocephali. Environ Biol Fish 39:339-355

McIlwain JL (2003) Fine-scale temporal and spatial patterns of larval supply to a fringing reef in Western Australia. Mar Ecol Prog Ser 252:207-222

Meinen CS, Garzoli SL, Johns WE, Baringer MO (2004) Transport variability of the Deep Western Boundary Current and the Antilles Current off Abaco Island, Bahamas. Deep-Sea Res I 51:1397-1415

Miller MJ (1995) Species assemblages of leptocephali in the Sargasso Sea and Florida Current. Mar Ecol Prog Ser 121: $11-26$

Miller MJ (2002a) Distribution and ecology of Ariosoma balearicum (Congridae) leptocephali in the western North Atlantic. Environ Biol Fish 63:235-252

Miller MJ (2002b) Contrasting migratory strategies of marine and freshwater eels. Fish Sci 68(Suppl I):37-40

Miller MJ, McCleave JD (1994) Species assemblages of leptocephali in the subtropical convergence zone of the Sargasso Sea. J Mar Res 52:743-772

Miller MJ, Tsukamoto K (2004) An introduction to leptocephali: biology and identification. Ocean Research Institute, University of Tokyo

Miller MJ, Otake T, Minagawa G, Inagaki T, Tsukamoto K (2002) Distribution of leptocephali in the Kuroshio Current and East China Sea. Mar Ecol Prog Ser 235:279-288

Miller MJ, Aoyama J, Mochioka N, Otake T, Castle PHJ, Minagawa G, Inagaki T, Tsukamoto K (2006) Geographic variation in the assemblages of leptocephali in the western South Pacific. Deep-Sea Res I 53:776-794

Minagawa G, Miller MJ, Aoyama J, Wouthuyzen S, Tsukamoto K (2004) Contrasting assemblages of leptocephali in the western Pacific. Mar Ecol Prog Ser 271:245-259

Moyer JT, Zaiser MJ (1982) Reproductive behavior of moray eels at Miyade-jima, Japan. J Ichthyol 28:466-468

Editorial responsibility: Howard Browman (Associate Editorin-Chief), Storebø, Norway
Olson DB, Schott FA, Zantopp RJ, Leaman KD (1984) The mean circulation east of the Bahamas as determined from a recent measurement program and historical XBT data. J Phys Oceanogr 14:1470-1487

Reverdin G, Niiler PP, Valdimarsson H (2003) North Atlantic Ocean surface currents. J Geophys Res 108:3002, doi:10. 1029/2001JC001020

Richardson DE, Cowen RK (2004) Diversity of leptocephalus larvae around the island of Barbados (West Indies): relevance to regional distributions. Mar Ecol Prog Ser 282: 271-284

Richardson PL (1983) Gulf Stream rings. In: Robinson AR (ed) Eddies in marine science. Springer-Verlag, New York, p 19-65

Ross SW, Rohde FC (2003) Collections of ophichthid eels on the surface at night off North Carolina. Bull Mar Sci 72: 241-246

Ross SW, Casazza TL, Quattrini AM, Sulak KJ (2007) Anguilliform larvae collected off North Carolina. Mar Biol 150: 681-695

Schmitz WJ Jr, McCartney MS (1993) On the North Atlantic circulation. Rev Geophys 31:29-50

Schoth M, Tesch FW (1982) Spatial distribution of 0-group eel larvae (Anguilla sp.) in the Sargasso Sea. Helgol Meeresunters 35:309-320

Schott F, Lee TN, Zantopp R (1988) Variability of structure and transport of the Florida Current in the period range of days to seasonal. J Phys Oceanogr 18:1209-1230

Shenker JM, Maddox ED, Wishinski E, Pearl A, Thorrold SR, Smith N (1993) Onshore transport of settlement-stage Nassau grouper Epinephelus striatus and other fishes in Exuma Sound, Bahamas. Mar Ecol Prog Ser 98:31-43

Smith DG (1989a) Family Muraenidae: Leptocephali. In: Böhlke EB (ed) Fishes of the Western North Atlantic. Mem Sears Found Mar Res 1(9):900-916

Smith DG (1989b) Family Congridae: Leptocephali. In: Böhlke EB (ed) Fishes of the Western North Atlantic. Mem Sears Found Mar Res 1(9):723-763

Smith DG, Miller MJ (1996) Cyematid larvae of the Leptocephalus holti group in the Atlantic and Pacific oceans (Pisces: Saccopharyngiformes). Breviora 503:1-12

Thorrold SR, Shenker JM, Wishinski E, Mojica R, Maddox ED (1994) Larval supply of shorefishes to nursery habitats around Lee Stocking Island, Bahamas. I. Small-scale distribution patterns. Mar Biol 118:555-566

Thresher RE (1984) Reproduction in reef fishes. Tropical Fish Hobbyist Publications, Neptune City, NJ

Tsukamoto K, Aoyama J, Miller MJ (2002) Migration, speciation and the evolution of diadromy in anguillid eels. Can J Fish Aquat Sci 59:1989-1998

Vukovich FM, Crissman BW (1978) Observations of the intrusion of a narrow warm tongue into the Sargasso Sea using satellite and in situ data. J Geophys Res 83:1929-1934

Wippelhauser GS, Miller MJ, McCleave JD (1996) Evidence of spawning and the larval distribution of nemichthyid eels in the Sargasso Sea. Bull Mar Sci 59:298-309

Wouthuyzen S, Miller MJ, Aoyama J, Minagawa G, Sugeha YH, Suharti S, Inagaki T, Tsukamoto K (2005) Biodiversity of anguilliform leptocephali in the central Indonesian Seas. Bull Mar Sci 77:209-224

Submitted: November 3, 2006; Accepted: February 16, 2007 Proofs received from author(s): July 26, 2007 